\title{
INTEGRATING PHOSPHORUS FERTILIZER RECOMMENDATION AND ENVIROMENTAL RISK INDEX OF SOIL TOTAL-P
}

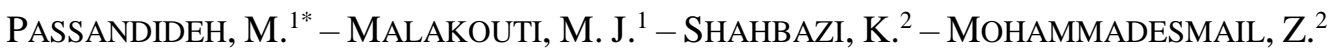 \\ ${ }^{1}$ Tarbiat Modares University, Tehran, Iran \\ (e-mail: Mpassandideh@yahoo.com; Mjmalakouti@modares.ac.ir) \\ ${ }^{2}$ Soil and Water Research Institute, Education and Extension Organization (AREEO), Tehran, Iran \\ (e-mail: shahbazikarim@yahoo.com; Mesmaily_n@yahoo.com) \\ *Corresponding author \\ e-mail: Mpassandideh@yahoo.com; phone: +98-914-193-1832
}

(Received 26 $6^{\text {th }}$ Dec 2018; accepted $25^{\text {th }}$ Feb 2019)

\begin{abstract}
Phosphorus (P) fertilizer application and increasing soil total P can cause environmental issues. Therefore, in the present study an experiment was carried out with optimal P-fertilizer recommendation based on the environmental aspects for two years ( 2015 \& 2016). In 2015, 90 soil samples were collected from agricultural lands of Iran and their environmental P index (EPI) was estimated. Also, through maize greenhouse cultivation, the available $\mathrm{P}$ critical level was determined. Then, $\mathrm{P}$ requirement for 90 fields was assessed based on EPI and soil available P. In 2016, through an onsite field experiment, the effects of $\mathrm{P}$ fertilizer levels on yield were estimated. The results revealed that the farmers are permitted to apply $\mathrm{P}$ fertilizer only at 8 fields out of 90 according to EPI. While based on the soil available P, 36 farms of 90 need to receive P-fertilizer, and the farmers can apply P fertilizer only at 4 fields out of 36 according to EPI. Considering EPI with no $\mathrm{P}$ application farmers faced a $23 \%$ yield reduction. If the farmers are not satisfied with this reduction, increasing EPI with P application should reduce soil erosion. Using a $50 \mathrm{~kg}$ $\mathrm{ha}^{-1} \mathrm{P}_{2} \mathrm{O}_{5}$ application should reduce soil erosion from 7 to 2 ton ha- ${ }^{-1}$.
\end{abstract}

Keywords: maize, $P$-accumulation, total phosphorus, $P$ index, $P$-fertilizer

\section{Introduction}

Phosphorous $(\mathrm{P})$, one of the macro elements essential for plant growth. Therefore, $\mathrm{P}-$ fertilizer application is crucial to reach the optimum economical yield. For decades, soil testing has been used for proper fertilization recommendation. In this method, the critical level of available $\mathrm{P}$ is considered as the criteria of P-fertilization (Malakouti, 2016). However, based on soil testing, P-fertilizer application may lead to Paccumulation, precipitation and increasing total $\mathrm{P}$ that may lead to environmental problems. It has been proven that most of the P-fertilizers $(\sim 80 \%)$ were precipitated in acidic soils (due to fixation by iron and aluminum oxides) and in calcareous soils (due to fixation by calcium carbonate) (Leytem and Mikkelsen, 2005). Recent studies have shown that soil total $\mathrm{P}$ is increased by long term $\mathrm{P}$-fertilizer application in many countries (Li et al., 2015; Wei-Xia et al., 2015; Wang et al., 2015; Powers et al., 2016). For instance, Sun et al. (2015) reported that on average about $1.1 \mathrm{mg}$ P-available per $\mathrm{kg}$ soil had been added to some Chinese soils annually in the 1997-2002 period. They also showed that the total $\mathrm{P}$ increased from 702 to $840 \mathrm{mg} \mathrm{kg}^{-1}$ from 1983 to 2002 . Xiaoying et al. (2015) showed that changes in soil Olsen-P follow the application of $\mathrm{P}$ fertilizer, so that each $100 \mathrm{~kg} \mathrm{P} \mathrm{ha}^{-1}$ surplus increase the Olsen-P by $1 \sim 6 \mathrm{mg} \mathrm{P} \mathrm{kg}^{-1}$. Their results also indicated that soil organic matter and $\mathrm{pH}$ have important effects on the changes in soil Olsen-P by $1 \mathrm{~kg} \mathrm{ha}^{-1}$ of P balance. 
When soils' $\mathrm{P}$ increases, soil water erosion and runoff may able to transfer it into the surface water, rivers, lakes, etc. This may lead to bio-environmental issues such as cultural eutrophication (Sharpley et al., 2003; Bolster et al., 2014). Cultural eutrophication is the process that speeds up natural eutrophication because of human activity. Natural eutrophication is when a body of water becomes overly enriched with minerals and nutrients that induce excessive growth of plants and algae (Schindler, 2012). Surveys showed that 54\% of lakes in Asia are eutrophic; in Europe, 53\%; in North America, 48\%; in South America, 41\%; and in Africa, 28\% (Ansari et al., 2010). On top of that based on scientific reports, in the region with enriched drinking water by $\mathrm{P}$, the health of habitants is in risk e.g. neurological disorders (Yang et al., 2008). Fataei (2010) reported results from a laboratory experiment designed to study pollution condition of the Aras River in Moghan. Agricultural lands around the Aras River in Moghan are intensively farmed, and $\mathrm{P}$ pollution to surface waters and Aras River via surface runoff resulting from application of P-fertilization is a major concern. He has reported that the concentration of phosphorus has increased from $0.10 \mathrm{mg} \mathrm{L}^{-1}$ at the beginning of the river to $0.44 \mathrm{mg} \mathrm{L}^{-1}$ at the end of the river. Stephen et al. (2016) investigate long-term accumulation and transport of anthropogenic phosphorus in three river basins. They presented an analysis of $\mathrm{P}$ fluxes in three rivers, including harvested crops, published data on P-fertilizer, sewages and river fluxes. Their analysis show that the magnitude of $\mathrm{P}$ accumulation has varied over the past 40-70 years in mixed agricultural-urban landscapes of the Thames Basin, UK, the Yangtze Basin, China, and the rural Maumee Basin, USA. They demonstrated that human-dominated river basins may undergo a prolonged but finite accumulation phase when $\mathrm{P}$ inputs exceed agricultural demand.

Heretofore environmental scientists of developed countries have been used and established indexes and tough rules and regulations for environmental protection purposes (Bolster, 2011). Phosphorus sorption index (PSI) (Sims et al., 2000), the simple soil test (STP) (Nelson and Shober, 2012), the degree of Phosphorus saturation (DPS) (Ige et al., 2005) and environmental P index (EPI) (Nelson and Shober, 2012) have been successfully applied for this aim.

Among these indicators, EPI is a more accurate and complete index due to incorporate into a single index, factors related to soil management and to P-transport (Sharpley et al., 2003). The most recent EPI was presented by Bolster et al. (2014) which was categorized in three levels as low (less than 40), moderate (between 40 to 100 ) and high (more than 100). Based on this index categories, P-fertilizer application is not allowed if the total $\mathrm{P}$ equal or higher than 800,600 and $400 \mathrm{mg} \mathrm{kg}^{-1}$, respectively. In this method, EPI influenced by various parameters such as the amount of $\mathrm{P}$ fertilizer, available $\mathrm{P}$, total $\mathrm{P}$, soil erosion and method of $\mathrm{P}$ fertilizer application.

In this index risk, the agricultural yield was not considered and the reduction in biomass has not been taken into account. In contrast, the environmental index risk is not considered by the agricultural engineers and their fertilization recommendations are based on crop yield and response to fertilizer. This indicates the existence of the gap between environmental and agricultural scientist's perspectives.

Overall, as mentioned above, traditional $\mathrm{P}$ fertilizer application can cause environmental issues in all over of the world and continuing this trend may increase crop yield and production but may destroy and damage the environment. So, it seems necessary to carry out the research to fill the gap between the two mentioned aspects in which the optimum yield with low environmental risk is achieved. 
The main aim of this study, that is conducted the first time till now, is assessing and investigating $\mathrm{P}$ fertilizer recommendation based on the combination of agricultural and environmental aspects. Within this research we are trying to answer the following questions "how would be the yield reduction if the farmers consider environmental risk index comparing to considering only soil testing analysis in P-fertilizer application?" and "if the yield reduction is not the favor of farmers and so they tend to apply maximum $\mathrm{P}$ fertilizer for maximum economical yield, what should they do to reduce environmental risk index?"

\section{Materials and methods}

At the present study, three experiments including determination of EPI, determination of available-P critical level for maize and field experiment were carried out to optimal P-fertilizer recommendation based on the environmental aspects in two years (2015 \& 2016).

\section{The Study area description}

This experiment was carried out in 90 fields of Moghan Agricultural lands. Moghan is located at latitudes $39^{\circ} 20^{\prime} \mathrm{N}$ and $47^{\mathrm{O}} 30^{\prime} \mathrm{E}$ with $40-50 \mathrm{~m}$ above sea level, in the NorthWest of Iran (Figure 1). The climate of this region is considered as semi-arid with average annual precipitation of $271.2 \mathrm{~mm}$. This region with more than 62024 hectares of cultivated land is surrounded by the Aras river. The river has got thousands of branches, so the eroded soils, sediments and runoff from these lands flow into this river. Aras river provides drinking water to tens of cities and villages and irrigation water to thousands of hectares of land (Nasrabadi et al., 2009).
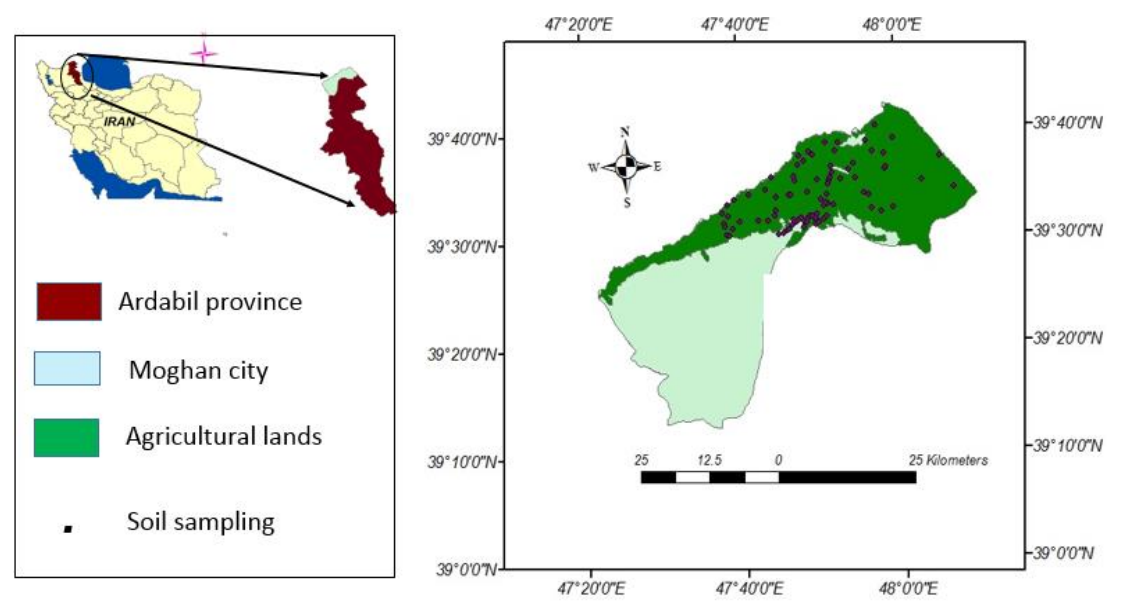

Figure 1. The location, layout and sampling locations of the study site

\section{First experiment: determination of EPI for 90 fields and assessment of the P-fertilizer recommendation}

In this part of the study, some soil factors such as soil total-P, available-P was obtained from laboratory analysis of soil samples. A number of other factors, including the method and amount of phosphate and organic fertilizers, were asked from farmers, and factors such as soil erosion were estimated from the defined models. 
The EPI, used in this study, was estimated based on the method presented by Bolster et al. (2014). In this section, the generalities are explained briefly. The general formula (Eq. 1) for EPI and how to calculate the sub-formulas can be written as:

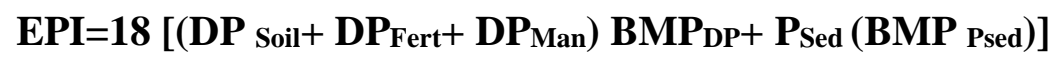

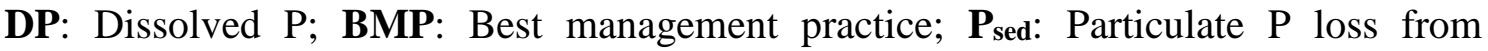
erosion; Fert: inorganic fertilizers; Man: organic fertilizers.

Where all the components are explained in detail as follow:

DPsoil estimation method: DPSoil refers to the part of the dissolved $\mathrm{P}$ in runoff released from the soil. The following equation $(E q .2)$ was used to calculate the $\mathrm{DP}_{\text {soil: }}$

$$
\text { DPSoil }=0.1 \times \mathrm{STP} \times \mathrm{PX} \times \mathrm{RQ}
$$

where STP is the amount of soil $\mathrm{P}\left(\mathrm{mg} \mathrm{kg}^{-1}\right)$. PX refers to the coefficient of $\mathrm{P}$ extraction $\left(\mu \mathrm{g} \mathrm{L}^{-1}\right)$, obtained from the relation, $\mathrm{Y}=1.8 \mathrm{X}+78.9$, where $\mathrm{Y}$ and $\mathrm{X}$ are PX $\left(\mu \mathrm{g} \mathrm{L}^{-1}\right)$ and soil $\mathrm{P}\left(\mathrm{mg} \mathrm{kg}^{-1}\right)$, respectively (Vadas et al., 2005; Bolster et al., 2014). $R Q$ is the average annual runoff $(\mathrm{cm})$.

DPfert estimation method: This identifies the role of chemical fertilizers used in runoff dissolved $\mathrm{P}$. The following equation (Eq. 3) was used to calculate this factor.

$$
\mathbf{D P}_{\text {Fert }}=0.5 \times 0.43 \times \mathrm{P}_{\mathrm{F}} \times(\mathrm{RQ} \div \mathrm{PT}) \times \mathrm{AF}_{\mathrm{F}}
$$

where DF is Amount of fertilizer added $\left(\mathrm{Kg}\right.$ P2O5 ha $\left.{ }^{-1}\right) . \mathrm{AF}_{\mathrm{F}}$ is related to the time and method of using the fertilizer. It is obtained from the tables provided by Bolster et al. (2014). PT refers to the average annual sediment $(\mathrm{cm})$ and is calculated from the following formula (Eq. 4).

$$
\mathbf{P T}=38.77 \mathrm{e}^{0.0353 \mathrm{R}}
$$

in which, $\mathrm{R}$ is degree of sedimentation (the total sum of the scores considered in the MPSIAC model), PT is annual deposition rate $\left(\mathrm{m}^{3} \mathrm{~km}^{-2}\right)$ and $\mathrm{P}_{\text {sed }}$ estimation method: In fact, this factor estimates the particulate $\mathrm{P}$ transferred by soil erosion. The following formula (Eq.5) was used to calculate it.

$$
\mathbf{P}_{\text {Sed }}=10^{-6} \times \mathrm{TP} \times \mathrm{SED} \times \mathrm{PER} \times \mathrm{SDR}
$$

where, $\mathbf{T P}$ is related to soil total $\mathrm{P}\left(\mathrm{mg} \mathrm{kg}^{-1}\right)$ which was obtained in this experiment by alkaline melting method for all the samples. SED refers to the annual average soil erosion $\left(\mathrm{kg} \mathrm{ha}^{-1}\right)$, which was estimated by the MPSIC method. PER refers to the ratio of soil particle enrichment, which means that fine particles are much richer in $\mathrm{P}$ than coarse particles. SDR refers to the proportion of sediment delivery and part of the amount of erosion soil that goes to the runoff.

$\mathbf{S D R}=1$ slope length $<3(\mathrm{~m}), \mathbf{S D R}=-0.17^{*}$ in (slope length) +0.9 slope length $\geq 3(\mathrm{~m})$.

In general, in this study, soil erosion estimated by MPSIC method. Modified Pacific Southwest Inter-Agency Committee (MPSIC) uses nine factors including geology, soil, climate (including isotherm and isohyets), runoff, topography (including elevation and land slope), land cover, land use, upland erosion, and channel erosion. The values of 
these factors are ranked based on the corresponding tables. Each of these factors is to be ranked based on a visual appraisal of the watershed. Generally, this model has been widely applied at a watershed scale in arid and semiarid regions of the USA and was assessed for its applicability to Iranian watershed environments (Bagherzadeh and Daneshvar, 2013). In Figure 2, a part of the water erosion is observed in the studied area.

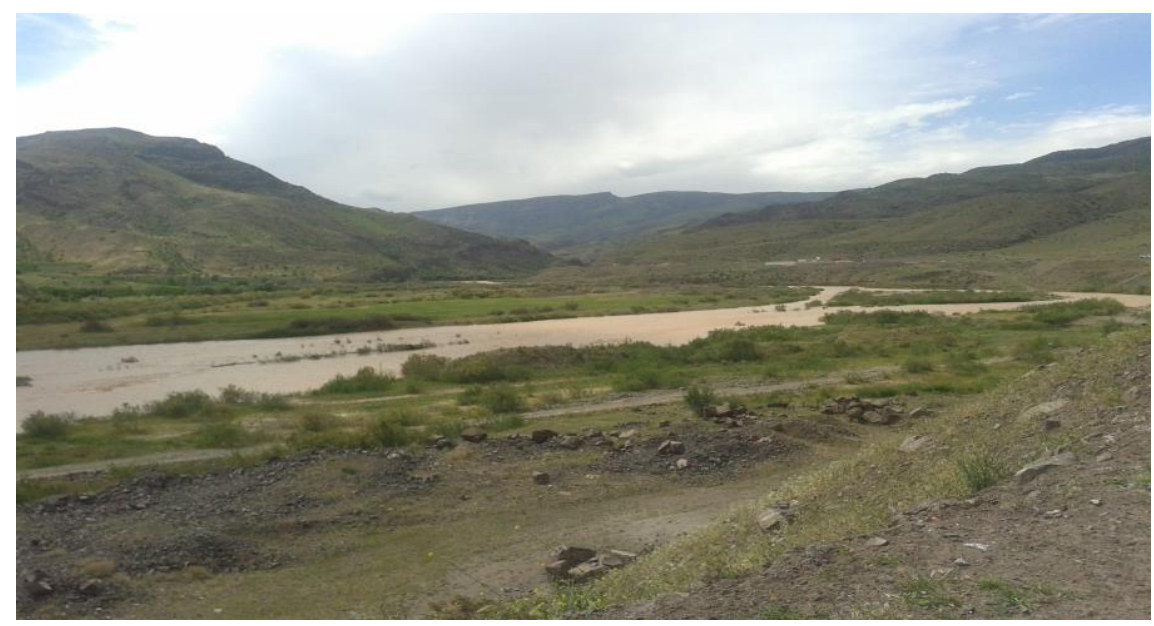

Figure 2. Flooding of river and eroded soils from the studied area

BMPDP and BMPPsed: are based on tables provided by Bolster et al. (2014). In fact, these are related to any land conservation operation that can reduce DP $\left(\mathrm{DP}_{\text {Soil }}+\mathrm{DP}_{\text {Fert }}+\mathrm{DP}_{\text {Man }}\right)$ and $\mathrm{P}_{\text {sed. }}$.

DP fert: Considering that the use of organic fertilizers in this area is negligible, this sector was considered insignificant.

Based on EPI explained above, P-fertilizer recommendation is summarized in Table 1 .

Table 1. Recommendation of P-fertilizer based EPI (Bolster et al., 2014)

\begin{tabular}{c|c|c}
\hline Range & Category & Interpretation \\
\hline \hline 0-40 & Low & If the soil total $\mathrm{P}$ is $\geq 800\left(\mathrm{mg} \mathrm{kg}^{-1}\right), \mathrm{P}$ - fertilizer should not be used \\
$\mathbf{4 0 - 1 0 0}$ & Moderate & If the soil total $\mathrm{P}$ is $\geq 600\left(\mathrm{mg} \mathrm{kg}^{-1}\right), \mathrm{P}$ - fertilizer should not be used \\
$>\mathbf{1 0 0}$ & High & If the soil total $\mathrm{P}$ is $\geq 400\left(\mathrm{mg} \mathrm{kg}^{-1}\right), \mathrm{P}$ - fertilizer should not be used \\
\hline
\end{tabular}

In this section of the study, for calculation and better interpenetrating the DOP (Deviation from optimal percentage) equation (Eq. 6) (Montanes et al., 1993) can be used as follow:

$$
\mathrm{DOP}=\left(\frac{\text { Soil total P }}{\text { Maximumacceptable } \mathrm{P}} * 100\right)-100
$$

In this equation soil total $\mathrm{P}$ and maximum acceptable $\mathrm{P}$ were driven based on EPI according to Table 1 . 


\section{Second experiment: determination of available-P critical level for maize and spatial assessment of P-fertilizer requirement}

In order to determine a critical level of available-P for maize (SC 704, $\left(\mathrm{MO}_{17} \times \mathrm{B}_{73}\right)$, in maturity group of late hybrid with a growth period of 274 days), the greenhouse experiment was carried out. The experimental design was randomized completely plots with two treatments and three replications. Initially, 30 soil samples with significant variation of available and total $\mathrm{P}$ were selected and $\mathrm{P}$-fertilizer treatments were applied at two levels of 0 and $100 \mathrm{~kg} \mathrm{ha}^{-1}$ from super phosphate $\left[\mathrm{CaH}_{4}\left(\mathrm{PO}_{4}\right)_{2} \mathrm{H}_{2} \mathrm{O}\right]$. To do so, 180 pots of $10 \mathrm{~kg}$ soil were used. The similar amount of other nutritious elements $\left(100 \mathrm{mg} \mathrm{kg}^{-1} \mathrm{~N}\right.$ from urea $\left[\mathrm{CO}\left(\mathrm{NH}_{2}\right)_{2}\right]$ in two times, $50 \mathrm{mg} \mathrm{kg}^{-1} \mathrm{~K}$ of potassium sulfate $\left(\mathrm{K}_{2} \mathrm{SO}_{4}\right), 20 \mathrm{mg} \mathrm{kg}^{-1} \mathrm{Mg}$ from magnesium sulfate $\left(\mathrm{MgSO}_{4}\right), 10 \mathrm{mg} \mathrm{kg}^{-1} \mathrm{Fe}$ from Iron sulfate $\left[\mathrm{Fe}_{2}\left(\mathrm{SO}_{4}\right)_{3}\right], 2 \mathrm{mg} \mathrm{kg}^{-1} \mathrm{Cu}$ from copper sulfate $\left(\mathrm{CuSO}_{4} .5 \mathrm{H}_{2} \mathrm{O}\right)$ and $2 \mathrm{mg} \mathrm{kg}^{-1}$ boron from boric acid $\left(\mathrm{H}_{3} \mathrm{BO}_{3}\right)$ ) were applied to all pots equally.

One day after soil amendment, six corn seedlings (pre-germinated by placing presoaked corn seeds on wet paper towels for five days) were transplanted per pot, and then thinned to two after one week. Pots were periodically weighed to maintain soil moisture at $80 \%$ field capacity. Corn was harvested after 185 days by cutting above-ground biomass at the soil surface, which was weighed. Then, critical level of available-P was calculated based on Cate and Nelson method (Cate and Nelson, 1971). Finally, the P requirement of 90 fields was compared and assessed with soil available $\mathrm{P}$ and measured critical level.

\section{Third experiment: field experiment and yield reduction estimation due to integrating environmental index and fertilizer recommendation}

The field experimental design was a randomized complete block design and three replications. Treatments were 0 (the control without $\mathrm{P}$ application), 100, 150, 200 and $250 \mathrm{~kg} \mathrm{ha}^{-1}$ of super phosphate. As mentioned above other nutrients were applied to all plots equally. The size of each plot was $3 \times 4 \mathrm{~m}$ in which 300 seeds were planted in each (in $20 \mathrm{~cm}$ interval). After harvesting, in addition to measuring $\mathrm{P}$ in the plant, the shoot yield of each treatment and environmental index of different treatments were calculated. In Figure 3, field experiment of corn cultivation is observed in the studied area.

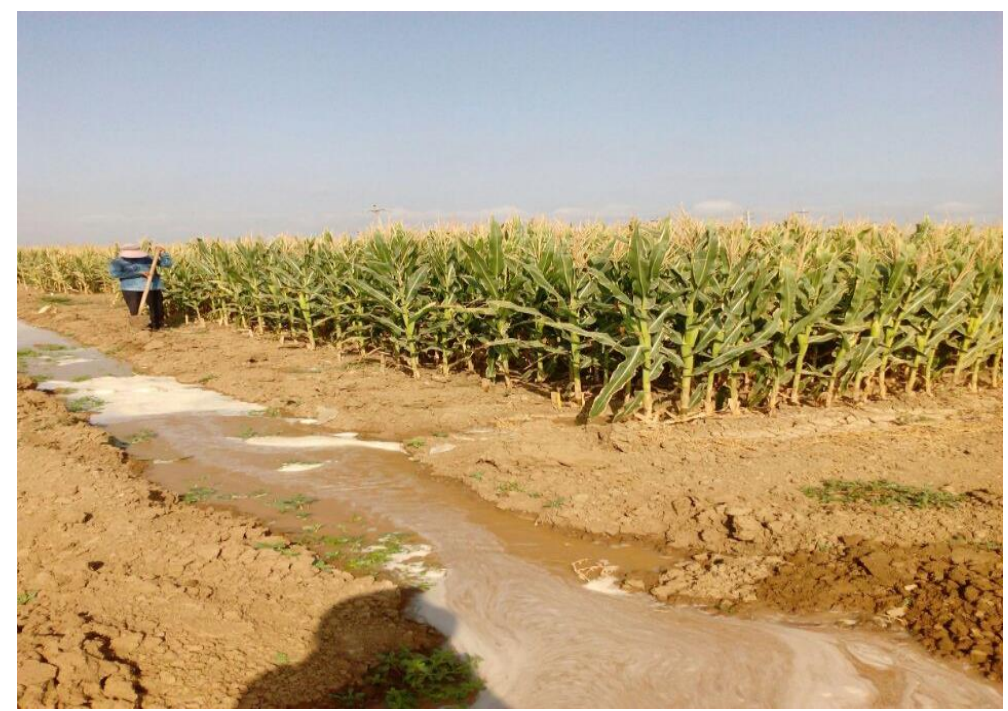

Figure 3. Field experiment of corn cultivation 


\section{Soil Samples laboratory analysis}

Soil samples were air-dried and sieved through $2 \mathrm{~mm}$ sieve. Soil properties were determined according to Page et al. (1982). Particle size analysis was made using the hydrometer method (Gee and Bauder, 1986). The $\mathrm{pH}$ of the soil samples was measured in a 1:1 (w/v) soil to water ratio suspension (McLean, 1982). Organic matter was measured using Walky and Black method (Nelson and Sommers, 1982). The available$\mathrm{P}$ and total-P were measured using the Olsen method (Olsen, 1954; Pasricha et al., 2002) and alkaline melting (Jackson, 1958), respectively.

\section{Investigating spatial variation and the mapping of variables}

To assess the spatial variability, first, the most important statistical description and distribution indexes were performed for all soil samples. The mean, min, max, variance, mod, skewness and coefficient of variation of available-P, total-P and EPI were calculated. The out of ranged data has been removed and some properties were logarithmically transformed to have a lognormal distribution. After all, the semivariogram was plotted and the correlation coefficient was evaluated. Statistical and geostatistical analysis have been performed using IBM SPSS (version 20) and GS+(version 5). For the statistical analysis, Analysis of variance (ANOVA) was used in combination with Duncan method at 0.05 significant different tests. The distribution maps of soil properties in the study area were mapped using ArcGIS (version 10.4).

\section{Results and discussion}

\section{Results of the first experiment}

\section{Determination of EPI for 90 fields and assessment of the P-fertilizer recommendation}

The EPI status of 90 fields of the study area is presented in Figure 4. The minimum and maximum and average values of EPI were 40, 72 and 55, respectively. According to categories and the recommendation of this index (Table 1), most of the fields are classified in medium level in view of risk assessment. In the fields with total-P more than $600 \mathrm{mg} \mathrm{kg}^{-1}$, application of $\mathrm{P}$ fertilizer is limited (Table 1).

Considering Eq. 6 shows that if DOP is positive it means soil total $\mathrm{P}$ was higher than total $\mathrm{P}$ of the environmental index and thus $\mathrm{P}$ fertilizer cannot be used in that field (and vice versa). Results of this part of study are shown in Figure 5. Results showed the farmers are permitted to apply $\mathrm{P}$ fertilizer only at 8 fields of 90 fields according to EPI. In other words, in case of plant requirement, $\mathrm{P}$ fertilizer application in current condition causes environmental degradation.

It should be noted that EPI has been introduced for decades in which the first one was presented by Lemunyon and Gilbert (1993). Reports and assessments based on EPI were presented by many environmental scientists. Heathwaite and Sharpley (1999) used the soil available $\mathrm{P}$ between 75 to $200 \mathrm{mg} \mathrm{kg}^{-1}$ as the critical level for environmental protection and $\mathrm{P}$ fertilizer application. This critical level was obtained based on significant statistical relation between available and soluble $\mathrm{P}\left(\mathrm{r}^{2}=0.58-0.98\right)$. Nair et al. (2004) reported the critical environmental index based on $\mathrm{P}$ saturation ratio (molar ratio of $\mathrm{P}$ to $\mathrm{Fe}+\mathrm{Al}$ ). Based on statistical relation between dissolved $\mathrm{P}$ in runoff and soil $\mathrm{P}$ saturation ration, they observed if $\mathrm{P}$ saturation ratio become more than a value (normally 0.1 ), the $\mathrm{P}$ concentration in runoff increased by applying $\mathrm{P}$ fertilizer. 
These methods are under critics by agricultural scientists. Because these recommendations are based only on environmental parameters and plant growth is not considered. Therefore, in such cases, a method that considers both the agricultural and environmental aspects is worthwhile (Malakouti, 2016).

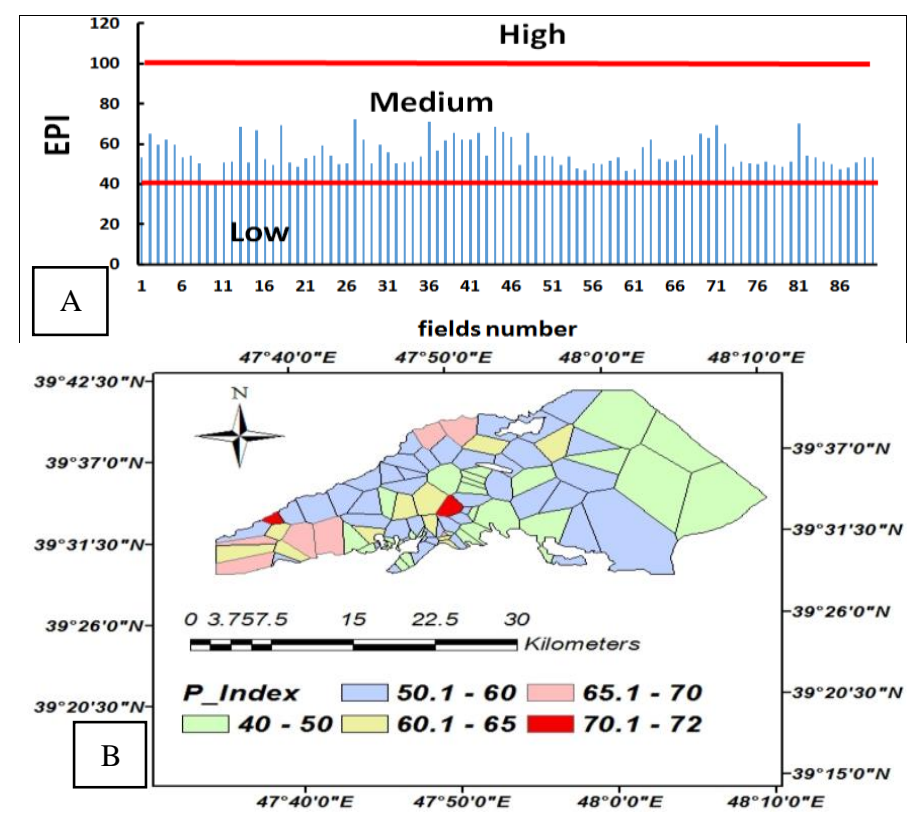

Figure 4. EPI values in the fields $(A)$ and zoning of agricultural fields based on EPI (B).

Low: $0<E P I<40$; If the soil total $P$ is $\geq 800\left(\mathrm{mg} \mathrm{kg}^{-1}\right)$, $P$-fertilizer should not be used.

Medium: $40<E P I<100$; If the soil total $P$ is $\geq 600\left(\mathrm{mg} \mathrm{kg}^{-1}\right), P$-fertilizer should not be used.

High: $100<E P I$; If the soil total $P$ is $\geq 400\left(\mathrm{mg} \mathrm{kg}^{-1}\right)$, $P$ - fertilizer should not be used (Bolster et al. 2014)

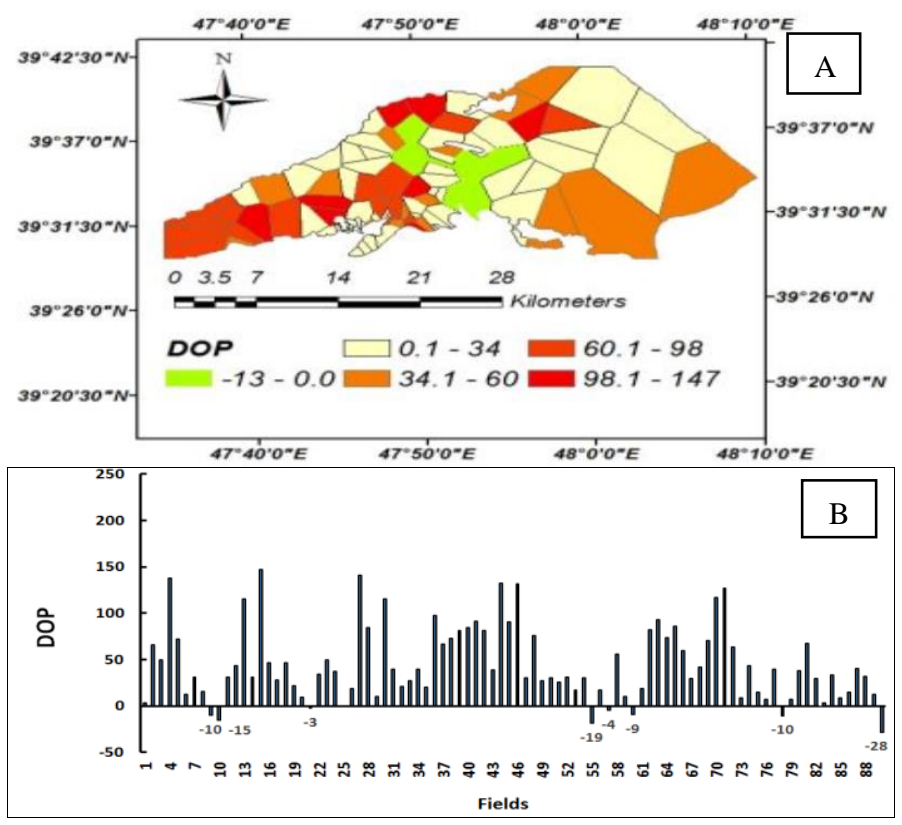

Figure 5. DOP values in the fields $(A)$ and zoning of agricultural fields based on DOP $(B)$. If $\boldsymbol{D O P}<0$, farmer can use $P$-fertilizer; If $\boldsymbol{D O P}>0$, farmer cannot use $P$-fertilizer 
The effects of soil total P and soil water erosion on EPI are indicated in Figure 6. According to scientific reports, soil water erosion is very effective in the runoff enrichment potential. So, deflation and some environmental indexes like phosphorus sorption index and degree of phosphorus saturation (because of ignoring the importance of soil erosion) cannot be accurately used to assess the potential of $\mathrm{P}$ losses from fields (Sims et al., 2000). Although in the studied area, the annual amount of rainfall is low, but a large part of the annual precipitation occurs in four months when the land is free of vegetation cover. This factor and other factors such as heavy texture, low organic matter, and low permeability caused high soil water erosion. Also, in this area, wind erosion (deflation) is less important because of the low wind speed. In general, the amount of phosphorus in the river is more affected by water erosion. Because, in the water erosion, all the eroded soil and both forms of phosphorus (dissolved and particulate P) enters the river. The significant correlation between EPI and soil total P and soil erosion indicates that EPI is strongly influenced by these parameters. $t$ is obvious that when soil total $\mathrm{P}$ is high, more $\mathrm{P}$ can be removed from the field with particles of soil. In this regard, scientists have criticized the accuracy of EPI in which soil total P is not involved (Bolstre et al., 2014).

Overall, from this part of the study, fields that EPI does not allow farmers to use Pfertilizers, was identified. It was also found that a farmer can reduce EPI by controlling soil erosion or reducing soil total $\mathrm{P}$. The important thing is that we must combine these finding with agricultural finding, which we have tried to do with the next experiments of this study.
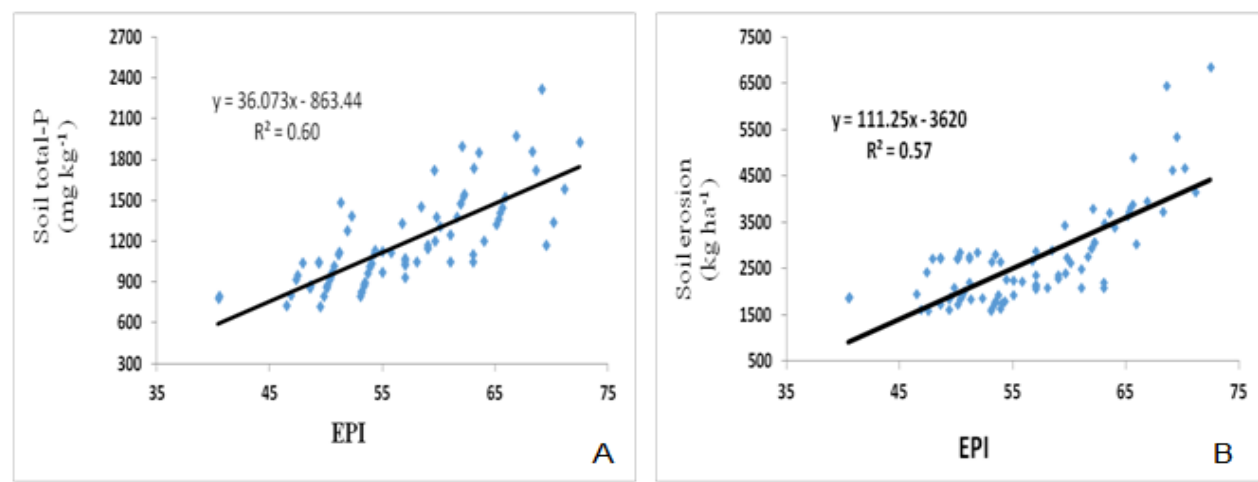

Figure 6. Relationship between EPI and soil total $P(A)$ and soil erosion (B)

\section{Investigation of spatial distribution of EPI and total P}

Some of the descriptive statistics of data and semivariogram of total P and EPI are shown in Table 2 and Figure 7, respectively. In this kind of experiments, understanding the variation of factors affecting soil total $\mathrm{P}$ and EPI are important whether from soil interstice properties (parent material or topography) or management practice (fertilizing) are affecting them. In geostatistics, it can be achieved by calculating spatial dependence of variables. Spatial dependence can be calculated by the effect of the part over the threshold level. If this ration is less than 25, or between 25-75 and higher than 75 so, spatial dependence is considered as high, moderate and week respectively (Chien et al., 1997). In most cases, high spatial dependence is affected by internal processes (parent material, hydrological situation, etc.) and week spatial dependence is affected by 
management practice and fertigation (Cambardella et al., 1994). According to variograms of variables (Figure 7), it can be noticed that both semivariograms of soil total $\mathrm{P}$ and EPI have the limits and are moderate spatial dependence. So, they are influenced by interstice soil properties and management practices.

Table 2. Descriptive statistics of soil total-P and environmental $P$ index data

\begin{tabular}{c|c|c|c|c|c|c|c|c}
\hline Factors & Minimum & Maximum & Average & Middle & Standard deviation & Variance & Skewness & Kurtosis \\
\hline $\begin{array}{c}\text { Soil total-P } \\
\left(\mathrm{kg} \mathrm{ha}^{-1}\right)\end{array}$ & 618 & 2315 & 1186 & 1107 & 331 & 1.1 & 0.36 & -0.74 \\
EPI & 40 & 72 & 55.5 & 53.4 & 7.2 & 51.9 & 0.30 & -0.48 \\
\hline
\end{tabular}

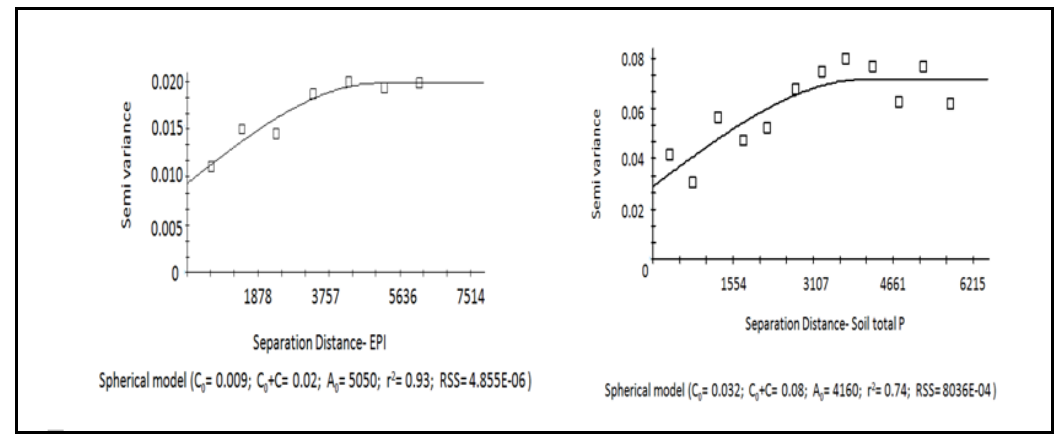

Figure 7. Semivariogram models fitted to studied variables (EPI and soil total P)

\section{Results of the second experiment}

Determination of available-P critical level for maize and assessing $P$ requirement for 90 fields

Figure 8 shows available $\mathrm{P}$ critical level of study soils (the data for this figure is provided in the Appendix). Critical level indicates field requirement to P-fertilizers but does not show the amount of $\mathrm{P}$ to be applied. As it is obvious, the critical level of soil available $\mathrm{P}$ was $13 \mathrm{mg} \mathrm{kg}^{-1}$ using Olsen method. For maize in various locations, different values were reported (Fernandes et al., 2000; Malakouti, 2016). The reasons for the differences may be climate conditions, soil texture, crop yield potential and etc. Results of assessing P requirement for 90 fields based on soil available P critical level are presented in Figure 9. Generally, 36 fields have got available P less than $13 \mathrm{mg} \mathrm{kg}^{-1}$. Many years ago, this method was one of the most principled methods of fertilizer recommendation in agriculture and many countries still use it.

Recently, the use of this method has been challenged due to increasing EPI and soil total-P (Gou et al., 2000; Ma et al., 2009; Malakouti, 2016). This method and phosphorus chemistry in the soil causes its accumulation in the soil. Thus, about $20 \%$ of the fertilizer that is consumed is absorbed by the plant and the remaining is deposited in acidic (high $\mathrm{Al}^{2+}$ and $\mathrm{Fe}^{3+}$ ) and calcareous (high $\mathrm{Ca}^{2+}$ ) soils (Marschner, 2011). Many researchers have reported that the use of $\mathrm{P}$ fertilizer based on this fertilization method, causes $\mathrm{P}$ accumulation in most regions of the world and in the future will restrict farmers in the use of P-fertilizers (Johnston and Steen, 2000; Li et al., 2015; Keke et al., 2016). In this regard, it has been reported that change in the current fertilizers recommendation is necessary because $\mathrm{P}$ accumulation subject (increasing EPI) is in contrast to sustainable agriculture (Malakouti, 2016). 


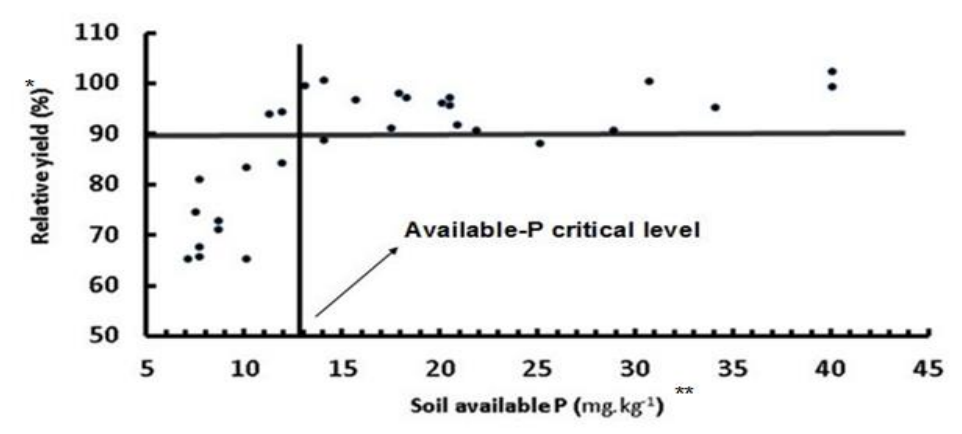

Figure 8. Determination of available-P critical level by Cate and Nelson Method (1971).

$*$ Relative yield $(\%)=($ yield of control treatment/yield of fertilizer treatment $) * 100$.

** Soil available-P is measured by Olsen method (Olsen 1954)

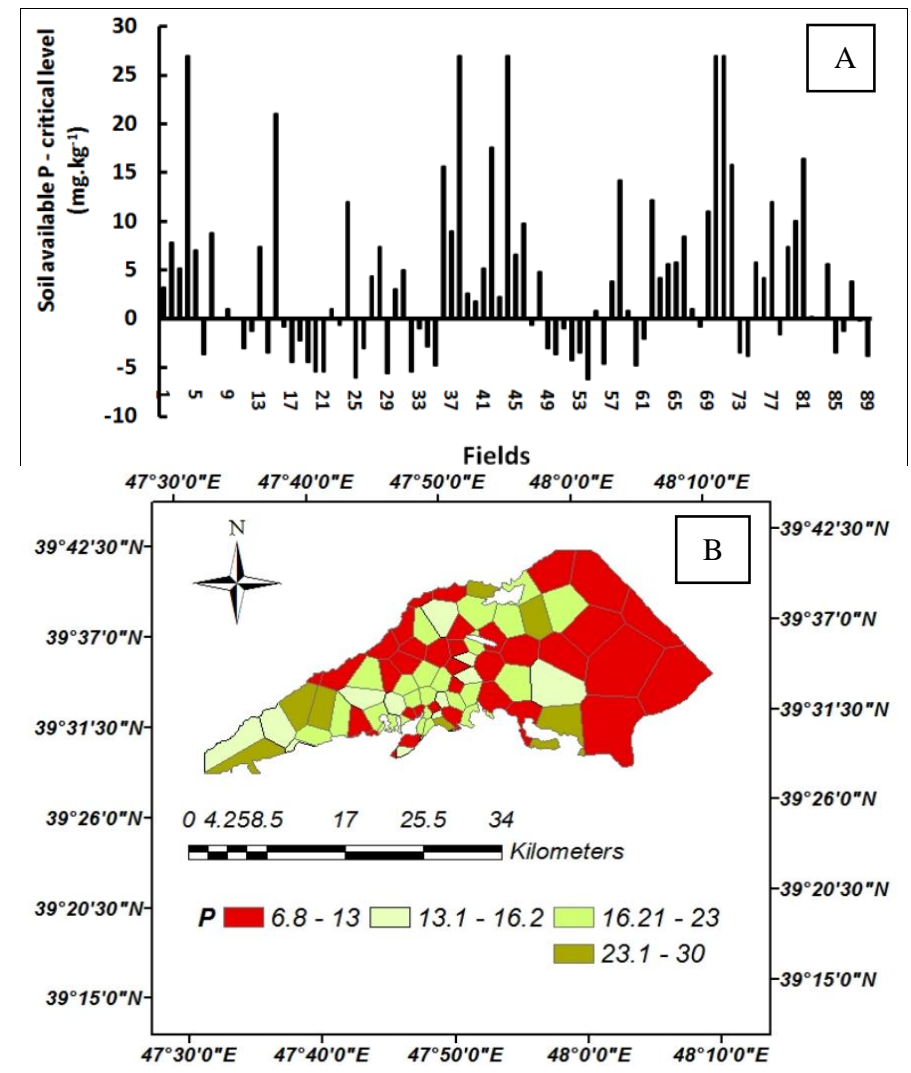

Figure 9. Available $P$ status of fields as compared to critical level $(A)$ and zoning of agricultural fields based on soil available $P(B)$. If (Soil available $P$ - critical level) $<0, P$ fertilizer should be used

Using the results of the first experiment and its match with the results of this part of study can help us.

Considering Figure 5 in which field were assessed based on EPI, it can be noticed that the farmers can apply P fertilizer only at 4 fields where their DOP are negative. In other fields, $\mathrm{P}$ application can causes environmental problems while they need Pfertilizer. Therefore in this case, the fields can be divided into 3 groups. First, the regions where do not need any $\mathrm{P}$ fertilizer; second the regions where need P-fertilizer 
and do not have any limitation for P application; and third the region where need for Pfertilizer but the application of $\mathrm{P}$ is limited by EPI. When a farmer cannot use Pfertilizer (based on EPI), he can take one of the following decisions:

- The farmer doesn't apply P-fertilizer and accept yield reduction. In this case, the state or the environmental organization must pay subsidies to farmers. Otherwise, it would be hard to recommend environmental indicators and acceptance of financial compensation for farmers.

- The farmer provides possibility of P-fertilizer by reducing EPI.

This issue can be examined in the next results of the present study.

\section{Third experiment}

In the field, experiment, available-P and total $\mathrm{P}$ were 8.6 and $1025 \mathrm{mg} \mathrm{kg}^{-1}$, respectively. In this field the EPI is 26 , in case of without $\mathrm{P}$ application and with erosion rate of 7 ton $\mathrm{ha}^{-1} \mathrm{y}^{-1}$. According to EPI (Table 1) $\mathrm{P}$ fertilizer is limited while based on low available $\mathrm{P}\left(<13 \mathrm{mg} \mathrm{kg}^{-1}\right) \mathrm{P}$ application is needed.

\section{Effects of $P$ fertilizer level on soil total $P$}

According to Table 3 and the soil $\mathrm{P}$ balance (amount of $\mathrm{P}$ extract by crop - applied $\mathrm{P}$ by fertilization ignoring runoff), 3.8, .24, 1.26, 2.7 and $6.02 \mathrm{mg} \mathrm{P}$ was added to each hectare while using $0,15,20,25$ and $35 \mathrm{~kg} \mathrm{P}_{2} \mathrm{O}_{5}$ per hectare respectively during growing season. However, these values are not comparable to soil total P. In other words, in the same condition the differences between total $\mathrm{P}$ and these values do not change EPI during a growing season. But for longer period fertilization can significantly effect on total P and EPI.

It should be mentioned that reports related to $\mathrm{P}$ application on increasing soil total $\mathrm{P}$ are based on long period i.e. 20 years. For instance, Sun et al. (2015) in their geostatistics study, investigated long period (20 years) of $\mathrm{P}$ accumulation in Chinese agricultural fields. They reported that $\mathrm{P}$ was added from 60 to $159 \mathrm{~kg} \mathrm{ha}^{-1}$ during 1982 until 2002 and soil total $\mathrm{P}$ increased from 0.72 to $0.84 \mathrm{gr} \mathrm{kg}^{-1}$ (16.7\%). Li et al. (2015) investigated long-term (20 years) $\mathrm{P}$ fertilizers application on soil available and total $\mathrm{P}$ and of rice. Their results showed $\mathrm{P}$ application increased soil total $\mathrm{P}$ considerably and changed it from 600 to $719 \mathrm{mg} \mathrm{kg}^{-1}$.

\section{Effects of P-fertilizer on yield, EPI and reduce EPI by controlling erosion}

Based on Table 3, considering EPI and no P application farmers faced with $23 \%$ yield reduction. If the farmers with any reason are not satisfied with this reduction, the minimum things to be done is considering the management practice in which EPI is not increased. In other words, increasing environmental index from $\mathrm{P}$ application is reduced by other factors like soil total $\mathrm{P}$ and soil erosion.

Based on short-term results there is not any option to reduce total $\mathrm{P}$ but based on Table 4 controlling soil erosion can be one of the immediate and effective solutions in protecting environment for farmers. According to Table 4, the farmers can reduce EPI by reducing erosion rate from 7 to 4 ton $\mathrm{ha}^{-1} \mathrm{y}^{-1}$ so they can apply $25 \mathrm{Kg} \mathrm{ha}^{-1} \mathrm{P}_{2} \mathrm{O}_{5}$ without increasing EPI. In the aim of this protocol, for using $50 \mathrm{~kg} \mathrm{ha}^{-1} \mathrm{P}_{2} \mathrm{O}_{5}$ the applicant should reduce soil erosion from 7 to 2 ton $\mathrm{ha}^{-1}$ where increasing EPI will not occur. 
Bolster (2014) showed that reducing water erosion by conservation practices can reduce $50 \%$ of EPI. In this study, in six fields with excessively high $\left(>2.24 \times 1000 \mathrm{~kg} \mathrm{ha}^{-1}\right)$ soil erosion rates, soil erosion was reduced by conservation practices such as buffer/filter strip, sediment basin, and water control structure and effect of soil erosion on environmental $\mathrm{P}$ index was investigated.

Table 3. Effects of P-fertilizer level on yield and bill of $P$ in soil

\begin{tabular}{c|c|c|c|c|c|c}
\hline \multirow{2}{*}{ Treatment } & $\begin{array}{c}\text { Added-P to } \\
\text { soil }\end{array}$ & $\begin{array}{c}\text { Yield (dry } \\
\text { weight) }\end{array}$ & $\begin{array}{c}\text { P concentration in } \\
\text { plant }\end{array}$ & $\begin{array}{c}\text { Removed-P by } \\
\text { plant }\end{array}$ & Soil P balance & Reduced yield \\
\cline { 2 - 7 } & \multicolumn{2}{|c|}{$\left.\mathbf{( k g ~ h a ~}^{-1}\right)$} & \multicolumn{2}{|c|}{$\left.\mathbf{( k g ~ h a ~}^{\mathbf{- 1}}\right)$} & $\%$ \\
\hline $\mathrm{T}_{0}$ & 0 & $7381^{1}$ & $0.15^{1}$ & $11.32^{1}$ & $11.32-$ & -23 \\
$\mathrm{~T}_{1}$ & 15 & $8737^{2}$ & $0.16^{1,2}$ & $14.27^{2}$ & 0.73 & -8.8 \\
$\mathrm{~T}_{2}$ & 20 & $9359^{3}$ & $0.17^{2,3}$ & $16.22^{3}$ & 3.78 & -2.3 \\
$\mathrm{~T}_{3}$ & 25 & $9564^{4}$ & $0.18^{3}$ & $16.90^{3}$ & 8.1 & -1.9 \\
$\mathrm{~T}_{4}$ & 35 & $9582^{4}$ & $0.18^{3}$ & $16.93^{3}$ & 18.07 & 0 \\
\hline
\end{tabular}

In each column, similar numbers indicate that meanings do not differ significantly in the $5 \%$ level Soil $\mathrm{P}$ balance= amount of $\mathrm{P}$ extract by crop - applied $\mathrm{P}$ by fertilization ignoring runoff

Table 4. Interaction of soil erosion and P-fertilizer on P environmental index

\begin{tabular}{c|c|c|c|c|c|c|c|c}
\hline \multirow{2}{*}{ P-fertilizer (kg P2O5 ha } & \multicolumn{1}{|c}{ Soil erosion $\left(\mathbf{k g ~ h a}^{-\mathbf{1}}\right)$} \\
\cline { 2 - 9 } & $\mathbf{0}$ & $\mathbf{1 0 0 0}$ & $\mathbf{2 0 0 0}$ & $\mathbf{3 0 0 0}$ & $\mathbf{4 0 0 0}$ & $\mathbf{5 0 0 0}$ & $\mathbf{6 0 0 0}$ & $\mathbf{7 0 0 0}$ \\
\hline 0 & 1 & 6 & 10 & 14 & 17 & 20 & 23 & $\underline{\mathbf{2 6}}$ \\
25 & 9 & 15 & 19 & 22 & $\mathbf{2 5}$ & 28 & 31 & 34 \\
50 & 17 & 23 & $\underline{\mathbf{2 7}}$ & 31 & 34 & 37 & 40 & 43 \\
75 & $\underline{\mathbf{2 6}}$ & 32 & 36 & 40 & 43 & 47 & 50 & 53 \\
100 & 35 & 41 & 45 & 48 & 51 & 54 & 57 & 60 \\
\hline
\end{tabular}

* Bold numbers are the minimum amount of EPI that farmer should avoid increasing it by appropriate ratio of P-fertilizer and soil erosion

\section{Conclusions}

Results of this study showed that minimum, maximum and mean of the EPI are 40, 72 and 55, respectively. According to categories and recommendations of the environmental index used in this study, only 8 fields of 90 fields are allowed to apply $\mathrm{P}$ fertilizers.

The soil available $\mathrm{P}$ of 36 fields was less than $13 \mathrm{mg} \mathrm{kg}^{-1}$ (critical level of available $\mathrm{P}$ ) and $\mathrm{P}$ fertilizer application is crucial. But based on EPI, P fertilizer can be applied only at 4 fields of 36 fields. $\mathrm{P}$ application can be depredated environment for other fields.

In the meanwhile, without $\mathrm{P}$ application, yield reduction will be about $23 \%$. If the farmers with any reason are not satisfied with this reduction, the minimum things to be done is considering the management practice in which EPI is not increased. In the other words, increasing EPI from $\mathrm{P}$ application is reduced by other factors like soil total $\mathrm{P}$ and soil erosion.

Results showed controlling soil erosion can be one of the immediate and effective solutions in protecting the environment for farmers.

It should be noted that the cumulative increasing of soil total $\mathrm{P}$ cannot be ignored. Because in short-term (one growing season) $\mathrm{P}$ application may not increase total $\mathrm{P}$ significantly, but in the longer period it can be influenced on to EPI. 
Finally, the uncertainty of the results for other region is obvious, but each researcher by applying this methodology can recommend fertilizer application more precisely and multi-purposes considering agro-environmental.

\section{REFERENCES}

[1] Ansari, A. A., Gill, S. S., Khan, F. A. (2010): Eutrophication: threat to aquatic ecosystems. - Eutrophication: causes, consequences and control, Springer: 143-170.

[2] Bagherzadeh, A., Daneshvar, M. R. M. (2013): Evaluation of sediment yield and soil loss by the MPSIAC model using GIS at Golestan watershed, northeast of Iran. - Arabian J of Geosci 6(9): 3349-3362.

[3] Bolster, C. H. (2011): A critical evaluation of the Kentucky phosphorus index. - J Ken Acad Sci. 72(1): 46-58.

[4] Bolster, C., Horvath, T., Lee, B., Mehlhope, S., Higgins, S., Delgado, J. (2014): Development and testing of new phosphorus index for Kentucky. - J Soil Water Conserv. 69(3): 183-196.

[5] Cambardella, C. A., Moorman, T. B., Parkin, T. B., Karlen, D. L., Novak, J. M., Turco, R. F., Konopka, A. E. (1994): Field-scale variability of soil properties in central Iowa soils. - Soil Sci Soc Am J. 58(5): 1501-1511.

[6] Cate, R. B., Nelson, L. A. (1971): A simple statistical procedure for partitioning soil test correlation data into two classes 1. - Soil Sci Soc Am J. 35(4): 658-660.

[7] Chien, Y.-J., Lee, D. Y., Guo, H. Y., Houng, K. H. (1997): Geostatistical analysis of soil properties of mid-west Taiwan soils. - Soil Sci. 162(4): 291-298.

[8] Fataei, A. (2010): Water quality survey of Aras River in Moghan. - Environmental Protection Agency of Iran 50(1): 72-81. (in Persian).

[9] Fernandes, M. L., Calouro, F., Indiati, R., Barros, A. M. (2000): Evaluation of soil test methods for estimation of available phosphorus in some Portuguese soils: A greenhouse study. - Com Soil Sci Plant Anal. 31(15-16): 2535-2546.

[10] Gee, G. W., Bauder, J. W. (1986): Particle-size analysis. - Methods of soil analysis: Part 1- Physical and mineralogical methods: 383-411.

[11] Guo, F., Yost, R., Hue, N., Evensen, C., Silva, J. (2000): Changes in phosphorus fractions in soils under intensive plant growth. - Soil Sci Soc Am J. 64(5): 1681-1689.

[12] Heathwaite, L., Sharpley, A. (1999): Evaluating measures to control the impact of agricultural phosphorus on water quality. - Water Sci Tec. 39(12): 149-155.

[13] Ige, D. V., Akinremi, O. O., Flaten, D. N. (2005): Environmental index for estimating the risk of phosphorus loss in calcareous soils of Manitoba. - J Environ Qual. 34(6): 19441951.

[14] Jackson, M. L. (1958): Soil chemical analysis. - Prentice-Hall, Inc.; Englewood Cliffs.

[15] Johnston, A., Steen, I. (2000): Understanding phosphorus and its use in agriculture. Euro. Fert. Manu. Assoc.

[16] Keke, H., Wenju, Z., Zhibin, G., Daozhong, W., Oene, O. (2015): Evaluating crop response and environmental impact of the accumulation of phosphorus due to long-term manuring of vertisol soil in northern China. - Agr. Eco. And Environ. 219: 101-110.

[17] Lemunyon, J. L., Gilbert, R. G. (1993): The concept and need for a phosphorus assessment tool. - J Product Agri. 6(4): 483-486.

[18] Leytem, A., Mikkelsen, R. (2005): The nature of phosphorus in calcareous soils. - Better Crops 89(2): 11-13.

[19] Li, Y., Rui, Y., Ru, G., Wei, H., Chen, A., Yong, L. (2015): Effects of long-term phosphorus fertilization and straw incorporation on phosphorus fractions in subtropical paddy soil. - J Integ Agric. 14(2): 365-373.

[20] Ma, B., Zhou, Z., Zhang, C., Zhang, G., Hu, Y. (2009): Inorganic phosphorus fractions in the rhizosphere of xerophytic shrubs in the Alxa Desert. - J Arid Environ. 73(1): 55-61. 
[21] Malakouti, M. J. (2016): Recommendation for Optimal Fertilizer Use in Agricultural Crops of Iran. - Moballeghan Publisher. Tehran, Iran (in Persian).

[22] Marschner, H. (2011): Marschner's mineral nutrition of higher plants. - Academic press.

[23] McLean, E. (1982): Soil pH and lime requirement. - Methods of soil analysis. Part 2. Chemical and microbiological properties: 199-224.

[24] Montanes, L., Heras, L., Abadia, J., Sanz, M. (1993): Plant analysis interpretation based on a new index: deviation from optimum percentage (DOP). - J Plant Nutri. 16(7): 12891308.

[25] Nair, V. D., Portier, K. M., Graetz, D. A., Walker, M. L. (2004): An environmental threshold for degree of phosphorus saturation in sandy soils. - J Environ Qual. 33(1): 107-113.

[26] Nasrabadi, T., Bidhendi, G. N., Karbassi, A., Hoveidi, H., Nasrabadi, I., Pezeshk, H., Rashidinejad, F. (2009): Influence of Sungun copper mine on groundwater quality, NW Iran. - Enviro Geology 58(4): 693-700.

[27] Nelson, D., Sommers, L. E. (1982): Total carbon, organic carbon, and organic matter. Methods of soil analysis. Part 2. Chemical and microbiological properties: 539-579.

[28] Nelson, N. O., Shober, A. L. (2012): Evaluation of phosphorus indices after twenty years of science and development. - J Environ Qual. 41(6): 1703-1710.

[29] Olsen, S. R. (1954): Estimation of available phosphorus in soils by extraction with sodium bicarbonate. - United States Department of Agriculture; Washington.

[30] Page, A., Miller, R., Kenney, D. (1982): Methods of Soil Analysis-Part 2. - No. 9, agronomy Series ASA, SSSA Publisher, Madison, Wisconsin, USA.

[31] Pasricha, N. S., Aulakh, M. S., Vempati, R. K. (2002): Evaluation of available phosphorus soil test methods for peanut in neutral and alkaline soils. - Communi Soil Sci Plant Analy. 33(19-20): 3593-3601.

[32] Powers, S. M., Bruulsema, T. W., Burt, T. P., Chan, N. I., Elser, J. J., Haygarth, P. M., Sharpley, A. N. (2016): Long-term accumulation and transport of anthropogenic phosphorus in three river basins. - Nature Geoscience 9(5): 353.

[33] Schindler, D. W. (2012): The dilemma of controlling cultural eutrophication of lakes. Proc. R. Soc. B: rspb20121032.

[34] Sharpley, A. N., Weld, J. L., Beegle, D. B., Kleinman, P. J. A., Gburek, W. J., Moore Jr., P. A., Mullins, G. (2003): Development of phosphorus indices for nutrient management planning strategies in the United States. - J Soil Water Conser. 58(3): 137-152.

[35] Sims, J., Edwards, A., Schoumans, O., Simard, R. (2000): Integrating soil phosphorus testing into environmentally based agricultural management practices. - J Environ Qual. 29(1): 60-71.

[36] Sun, W. X., Huang, B., Qu, M. K., Tian, K., Yao, L. P., Fu, M. M., Yin, L. P. (2015): Effect of farming practices on the variability of phosphorus status in intensively managed soils. - Soil Sci Soc China 25-3: 438-449.

[37] Vadas, P., Kleinman, P., Sharpley, A., Turner, B. (2005): Relating soil phosphorus to dissolved phosphorus in runoff. - J Environ Qual. 34(2): 572-580.

[38] Wang, R., Guo, S., Li, N., Li, R., Zhang, Y., Jiang, J., Wang, Z., Liu, Q., Wu, D., Sun, Q. (2015): Phosphorus accumulation and sorption in calcareous soil under long-term fertilization. - PloS one 10(8): e0135160.

[39] Wei-Xia, S., Huang, B., Ming-Kai, Q., Kang, T., Li-Peng, Y., Ming-Ming, F., Li-Ping, Y. (2015): Effect of farming practices on the variability of phosphorus status in intensively managed soils. - Pedosphere 25(3): 438-449.

[40] Yang, X. E., Wu, X., Hao, H. L., He, Z. L. (2008): Mechanisms and assessment of water eutrophication. - J Zhejiang Univ Sci. 9(3): 197-209.

[41] Zhan, X., Zhang, L., Zhou, B., Zhu, P., Zhang, S. (2015): Changes in Olsen phosphorus concentration and its response to phosphorus balance in black soils under different longterm fertilization patterns. - PLoS ONE 10(7): e0131713. 


\section{APPENDIX}

Table A1. Physical and chemical characteristics of soils used in potting and the effective of $P$ treatments on yield

\begin{tabular}{|c|c|c|c|c|c|c|c|c|}
\hline \multirow{2}{*}{ Soil } & Total P & Ava. P & \multirow{2}{*}{$\begin{array}{c}\text { pH } \\
(1: 2)\end{array}$} & O.C & Clay & \multicolumn{2}{|c|}{ Yield } & \multirow{2}{*}{ Relative yield \% } \\
\hline & \multicolumn{2}{|c|}{$\mathrm{mg} \mathrm{kg}^{-1}$} & & \multicolumn{2}{|c|}{$\%$} & $\mathbf{T}_{\mathbf{0}}$ & $\mathbf{T}_{1}$ & \\
\hline 1 & 800 & 7.0 & 8.1 & 1.47 & 40 & 35.0 & 53.7 & 65 \\
\hline 2 & 883 & 7.4 & 7.8 & 0.57 & 35 & 36.1 & 48.5 & 74 \\
\hline 3 & 800 & 7.6 & 7.8 & 2.42 & 50 & 35.9 & 53.2 & 67 \\
\hline 4 & 875 & 7.6 & 7.8 & 1.27 & 43 & 35.2 & 53.6 & 66 \\
\hline 5 & 1248 & 7.6 & 7.7 & 0.80 & 51 & 37.7 & 46.7 & 81 \\
\hline 6 & 1025 & 8.6 & 7.8 & 1.72 & 38 & 37.9 & 53.4 & 71 \\
\hline 7 & 1025 & 8.6 & 7.8 & 1.72 & 38 & 38.5 & 52.9 & 73 \\
\hline 8 & 1050 & 10.0 & 7.8 & 1.94 & 43 & 35.3 & 54.1 & 65 \\
\hline 9 & 1175 & 10.0 & 7.9 & 1.47 & 48 & 48.0 & 57.7 & 83 \\
\hline 10 & 1150 & 11.8 & 7.8 & 0.87 & 25 & 55.2 & 56.6 & 84 \\
\hline 11 & 1275 & 10.2 & 7.8 & 1.52 & 38 & 53.4 & 56.6 & 94 \\
\hline 12 & 1300 & 11.4 & 7.7 & 3.11 & 40 & 51.1 & 54.5 & 94 \\
\hline 13 & 780 & 13.0 & 7.7 & 1.25 & 45 & 52.1 & 52.0 & 99 \\
\hline 14 & 825 & 14.0 & 7.6 & 1.48 & 53 & 49.0 & 55.2 & 89 \\
\hline 15 & 925 & 14.0 & 7.5 & 1.48 & 55 & 52.1 & 51.8 & 101 \\
\hline 16 & 1448 & 15.6 & 7.8 & 0.88 & 20 & 53.8 & 55.7 & 97 \\
\hline 17 & 1925 & 17.4 & 7.8 & 1.19 & 33 & 52.3 & 57.5 & 91 \\
\hline 18 & 1405 & 17.8 & 7.9 & 1.09 & 35 & 55.8 & 57.0 & 98 \\
\hline 19 & 1200 & 18.2 & 7.6 & 1.55 & 55 & 54.5 & 56.2 & 97 \\
\hline 20 & 1375 & 20.0 & 7.1 & 1.45 & 50 & 54.2 & 56.4 & 96 \\
\hline 21 & 1475 & 20.4 & 7.8 & 1.33 & 35 & 51.2 & 53.6 & 96 \\
\hline 22 & 1725 & 20.4 & 8.0 & 1.07 & 38 & 52.3 & 53.9 & 97 \\
\hline 23 & 1325 & 20.8 & 7.6 & 1.86 & 50 & 50.2 & 54.8 & 92 \\
\hline 24 & 1050 & 21.8 & 7.7 & 2.45 & 45 & 47.6 & 52.5 & 91 \\
\hline 25 & 1100 & 25.0 & 7.7 & 2.04 & 38 & 48.2 & 54.7 & 88 \\
\hline 26 & 1310 & 28.8 & 7.7 & 2.41 & 48 & 47.4 & 52.3 & 91 \\
\hline 27 & 1450 & 30.6 & 7.9 & 1.13 & 33 & 52.3 & 52.1 & 100 \\
\hline 28 & 1975 & 34.0 & 7.9 & 7.01 & 45 & 47.5 & 49.9 & 95 \\
\hline 29 & 1738 & 40.0 & 7.7 & 2.84 & 35 & 54.3 & 53.1 & 102 \\
\hline 30 & 1900 & 40.0 & 8.2 & 1.98 & 35 & 54.3 & 54.7 & 99 \\
\hline
\end{tabular}

Ava.: Available; O.C: Organic carbon; T.N.V ; T0: Control treatment; $\mathbf{T}_{\mathbf{1}}$ : Fertilizer treatment

Relative yield $(\%)=($ yield of control treatment/yield of fertilizer treatment $) * 100$ 